\title{
Loyalty (The National Principles): Strengthening Eco-Tourism Industry in Sabah, Malaysia
}

\author{
Romzi A., Ahmad Tarmizi A. R., Mansur T., Anna Lynn A. B., Budi Anto M. T. \& Nordin, M. \\ CPKLL, Universiti Malaysia Sabah, Kota Kinabalu, Malaysia
}

Received: September 21, 2010

Accepted: February 21, 2011

doi:10.5539/jsd.v4n2p184

\begin{abstract}
The purpose of this study was to investigate the youth's perception on the influences of the second National Principles (Rukun Negara no. 2) that is 'loyalty to the king and country' towards the eco-tourism industry in Sabah, Malaysia. This study aims to determine the positive and negative influences of the second National Principles (NP) on the eco-tourism industry; and to determine the factor associated most with the success of eco-tourism industry in relation to the second NP as perceived by youth in Sabah, Malaysia. The data were collected through a self administered questionnaire and later analyzed using SPSS. In this study, 100 youth were selected as respondents with a mean age of 27 . This study found that there is a positive influence but no negative influence of the second NP on the eco-tourism industry in Sabah, Malaysia. The factor associated most with the success of eco-tourism industry in relation to the second NP as perceived by youth in Sabah, Malaysia is ethical and moral values. In accordance, professional experience, and the use of a specific formula may provide a suitable basis for change in this industry when dealing with the local perception on their responsibility to make this industry develop in relation to their feeling of concern towards 'loyalty to the king and country'.
\end{abstract}

Keywords: National Principles (Rukun Negara), Eco-Tourism

\section{Introduction}

World Travel and Tourism Organization and International Hotel and Restaurant Association (1999) recited that travel and tourism has a number of advantages over the industry sector. The advantages includes creating jobs and wealth whilst at the same time, contributing to sustainable development; tends to have low start-ups costs; having viable option in a wide range of areas and regions; continuing to grow for the foreseeable future; and the industry is, in a large part, aware of the need to protect the resource on what it is based-local culture and built and natural environment - and it committed to these resources preservation and enhancement.

In Sabah, Malaysia, several organizations whether from public agencies or private companies are actively promoting eco-tourism industry as an effort to increase the natural-based economic improvement and utilizing natural resources effectively to eradicate poverty profile. This promising industry enables Sabah to transform its' economic status as compared to the previous and present situations. In this context, eco-tourism industry must be more developed in order to create a new look of natural-based economic environment. It can also be geared when the general public are aware and understand the National Principles especially the second principle namely 'loyalty to the king and country'. This development agenda would bring about the transformation of Sabah's economic perspectives which focuses on sustainable development especially when dealing with rural communities.

Thus, the study on the influences of any specific national principles must be carried out to ensure it happens continuously. The researchers are positive that this study will contribute to the understanding of the inter-correlation between second NP and the success of eco-tourism industry in Sabah, Malaysia as well as this industry considered as a tool for rural standard of living improvement effort. Hence, improve the eco-tourism industry which is geared by the National Principles.

\section{Problem Statement}

The term loyalty is often described as an interpersonal and not suprapersonal such as a relationship between persons (Duska, 2007). It may certainly be between two persons that may lead to the formation of a group of persons. In Malaysia there is a principle which discusses the term loyalty in a very crucial manner. This refers to the second principles in the 'Rukun Negara' (National Principles) that is "loyalty to the king and country". The National Principles (NP) is the Malaysian declaration of national philosophy instituted by royal proclamation on the most important event namely 'Merdeka Day-1970. It has been proclaimed in response to the serious race riot in May 13, 1969 (Shamsul, 2007: 121) 
Loyalty to the king and country (the second NP) is likely to have influences on the development of various aspects of this country (Malaysia). Among the relevant aspects is the eco-tourism industry. The influences may seek from the possible relationship between the awareness among the general public of the second NP and the success of eco-tourism industry. Hence, questions arise concerning the influences of the second NP that is 'loyalty to the king and country' on the eco-tourism industry in Sabah. For instance, are they any negatives or positives influences of the second NP on the eco-tourism industry in Sabah? So far, no study has been conducted in this area in a specific and systematic manner. Since the eco-tourism is one of the sustainable development agenda pursued by the Sabah state government, it would be interesting and suitable to investigate the relationship between the second NP and the eco-tourism industry in order to address the following questions:

1) Are there any positive influences of the second NP on the eco-tourism industry in Sabah, Malaysia?

2) Are there any negative influences of the second NP on the eco-tourism industry in Sabah, Malaysia?

3) What are the factors associated most with the success of eco-tourism industry in relation to the second NP as perceived by the youth in Sabah, Malaysia?

\section{Objectives of the Study}

The general objective of this exploratory study is to investigate youth's perception on the influences of the second NP that is 'loyalty to the king and country' towards the eco-tourism industry in Sabah, Malaysia.

Specific objectives of the study are stated as follows:

1) To determine whether there is any positive influence of the second NP on the eco-tourism industry in Sabah, Malaysia.

2) To determine whether there is any negative influence of the second NP on the eco-tourism industry in Sabah, Malaysia

3) To identify the factors associated most with the success of eco-tourism industry in relation to the second NP as perceived by youth in Sabah, Malaysia.

\section{Methodology}

\subsection{Research Design}

The main objective of this study was to investigate the youth's perceptions on the influences of the second NP towards the eco-tourism industry in Sabah, Malaysia. This study used a quantitative methodology of cross-sectional design since a statistically significant sample of a population was used to estimate the relationship between the variables. This exploratory research is a cross-sectional study whereby the data collection was done once without extended period or having to conduct two data collection sessions. In this case, the researchers defined this study based on the Barbie (1995), and Agresti \& Finlay (1986) definition of the research time dimension, which according to them; cross-sectional study is a research work that is designed to study some phenomenon by taking a cross section of it at one time and analyzing that cross section carefully.

\subsection{Population and Sampling}

The objective of the research is to make an inference of the population based on characteristics of the sample. According to Barbie (1995), careful probability sampling provides a group of respondents whose characteristics may be taken to reflect those of a larger population, and carefully constructed standardized from all respondents. Hence, a sampling design that simplified the process of distributing and collection of completed questionnaires sets (research instrument) of this study is purposive random sampling technique. The respondents for this study are categorized into two groups as shown as in Table 1 (see appendix 1)

\subsection{Research Instruments}

The primary data for this study was gathered through a set of questionnaires, which is designed to elicit the required answers. This self-administered questionnaire was originally written in English and translated into Malay language, the language spoken by all respondents.

There are 40 items available in the self-administered questionnaires in order to identify the influences of second $\mathrm{NP}$ on the success of eco-tourism industry, and also to identify the factors associates most with the success of eco-tourism industry in Sabah, Malaysia. The overall Cronbach's Alpha value showed a high reliability (.7879). The validity was approved by the experts as it has fulfilled the criteria needed. Hence, the set of self-administered questionnaire possesses high reliability and validity, and suited to use for this study. 


\subsection{Analysis of Data}

The data was collected using a set of questionnaire analyzed using SPSS, version 17. This computer software was used as this software gives the needed numerical interpretation. Moreover, this software was found as suitable to the study as according to Kinner \& Gay (2000), SPSS is a modern statistical computer package that is developed to organize; to describe; and to analyze research data and it is most suitable for quantitative research.

\section{Findings}

The findings of this study posited as follows:

\subsection{Respondents Background}

Response rate of 100 percent was attained $(\mathrm{N}=100)$. Besides, 50 percent of the respondents were urban youth and the other 50 percent were rural youth. Moreover, 40 per cent of respondent were males, while 60 percent of respondent were females. Mean age was 27 years. 60 percent of the respondent were had either Form 5 certificate or Form 6 Certificate, with the remaining 40 percent of the respondents were with Form 3 certificate.

\subsection{The Influences of Second NP on Eco-Tourism}

The influences of second NP on the success of eco-tourism industry in Sabah, Malaysia measured by evaluating the overall element of the second NP which consists of loyalty to the king [Yang di-pertuan Agong (YDPA)] and country, honest to the YDPA and country, and sincere to the YDPA and country. In this study, the researchers concluded that if there is significant relationship between any one of the major element of second NP and the success of eco-tourism industry in Sabah, Malaysia then it confirms that there is positive influence of any one of the major element of second NP on the success of eco-tourism industry in Sabah, Malaysia. In contrast, if there is no significant relationship between any one of the major element of second NP and the success of eco-tourism industry in Sabah, Malaysia then it confirms that there is a negative influence of any one of the major element of second NP on the success of eco-tourism industry in Sabah, Malaysia.

The results shown in Table 2 (see appendix 1) revealed that there is a positive relationship between the overall elements of second NP and the success of eco-tourism industry in Sabah, Malaysia. It confirms that there is a positive influence of the second NP on the success of eco-tourism in Sabah, Malaysia which characteristic by the three main elements of the second NP. This study also revealed that there is no negative relationship between the second NP and the success of eco-tourism industry in Sabah. This probably means that there is no negative influence of the second NP on the success of eco-tourism industry in Sabah.

There are several possible explanations on the positive influences of the second NP towards the success of eco-tourism industry in Sabah. One is that as people become more loyal to their king and country, the less time they have to actually make use of eco-tourism industry as their own business rather than representing the country and shows the tourist how much they love the king and the country. Another possible reason is that the more concern the individuals towards their country, the more sensitive they will be towards the natural heritage belongs to their country. Therefore, loyalty to the king and country will prevent violence and destruction of the natural heritage which later benefited them. A third possible reason for this positive influence is simply that with the increase of awareness on the second NP, and individuals tend to use the eco-tourism industry as a platform to introduce and increase the country's image through tourism industry.

5.3 Factors Associated Most with the Success of Eco-tourism Industry in Relation to the Second NP (Loyalty to the King and Country)

In this study, the factors associated with the success of eco-tourism industry in relation to the second NP suggested are including ethical/moral values, doctrinal/ideological values (political and religious), social values and aestheticism values. All of these suggested values are among the personal and cultural values. These values are needed to be taken into account in this study as according to Santrock (2007), value clarification is needed to help people clarify what their lives are for and is it worth working for.

The stepwise regression analysis for the data revealed that the Success of Eco-Tourism Industry in Sabah could be predicted from ethical and moral values, social values and aestheticism values (see Table 3 in Appendix 2). The ethical and moral values $(\beta=0.003 ; P<.05)$ emerged as the most significant predictors to the success of eco-tourism in Sabah. In short, the factor associated most with the success of eco-tourism industry in Sabah, Malaysia in relation to second NP is ethical and moral values. This result suggested that the ethical and moral values have to be the most important factors to be taken into consideration when dealing with activities to develop eco-tourism industry in relation to the second NP. The social values factor $(\beta=0.033 ; P<0.05)$ also emerged as a significant predictor to the success of eco-tourism industry in relation to the second NP. The other 
factor that emerged as a significant predictor to the success of eco-tourism industry in relation to the second NP is aestheticism values $(\beta=0.323 ; P<0.05)$.

However, the regression analysis for the data revealed that the Success of Eco-Tourism Industry in Sabah couldn't be predicted by doctrinal/ideological values. The doctrinal/ideological values $(\beta=0.452 ; P>0.05)$ emerged as not the significant predictors to the success of eco-tourism in Sabah, Malaysia. This result suggested that the doctrinal/ideological values are not really needed to be taken into consideration when dealing with activities to develop eco-tourism industry in relation to the second NP.

Theoretically, these findings have provided some supports to the issue that is, how to strengthen or develop the eco-tourism industry in Sabah, Malaysia. In ethicality judgments, all respondents of this study relied to some extent on the evaluation of various characteristics of the moral issue. Minimally however, different group of respondents may not only place differential weight on personal understanding of the second NP (loyalty to the king and country), but may also utilize a different subset of the value/intensit.

\section{Recommendations}

Based on the findings shown in the previous page, the researchers concluded that there is positive significant influence of the second NP (Rukun Negara no. 2) on the success of eco-tourism industry in Sabah, Malaysia. But, there is no negative influence of the second NP (Rukun Negara no. 2) on the success of eco-tourism industry in Sabah, Malaysia. Moreover, the factors associated most to the success of the success of eco-tourism industry in Sabah, Malaysia in relation to the second NP is ethical and moral values, followed by social values and aestheticism values. Thus the researchers found that there are possible actions that can be utilized to improve the eco-tourism industry in Sabah, Malaysia when at the same time dealing with the 'loyalty to the king and country' as posited as follows:

6.1 The study on the psychological aspect (emotion) in relation to the second NP need to be carried out in order to make it more determined;

\subsection{Social, economic and political policy need to be balanced to make this promising industry more developed;}

6.3 Eco-tourism information has to be widen spreadhead through effectives and efficience way especially by included the professionals body in each program related to it. Through these programmes the second National principles (loyalty to the king and country) must be the first priority to be implemented;

6.4 Professional experience, and the use of the specific formula must be used as the basis for change in this industry, particularly when dealing with the local perceptions on their responsibility to make this industry grows faster in relation to their feelings of concern towards 'loyalty to the king and country';

6.5 Promoting eco-tourism industry that is strongly characterized by the National Principles especially the second NP namely loyalty to the king and country. This can be done through concentration on the activities that can popularize the National Principles among the general public and later depict to the tourist of how we love our country; and

6.6 Strengthening the linkages or cooperation between several agencies and populace in order to make eco-tourism success without taken aside all aspect of nation-building.

\section{Conclusion}

The second National Principle (Rukun Negara no. 2) make a considerable impact as well as an influnec for both positive and negative on eco-tourism industry development in Sabah, Malaysia. Is it feasible to expect psychological aspect (emotion) need to be more determined; social, economic and political policy to be balanced and eco-tourism information has to be widen spreadhead through effective and efficient way. Professional experience, and the use of the specific formula may provide a suitable basis for change in this industry, particularly when dealing with the local perceptions on their responsibility to make this industry grows faster in relation to their feelings of concern towards 'loyalty to the king and country'. Every single person in this country must clearly understand the significance of the second NP in their life and to its relevant indicators.

However, all these briliant ideas would not be enough if there is no strong support given by the nation. Without support and monitor, and encouragement to forge better understanding towards the impacts of loyalty to the king and country on the eco-tourism industry development, this industry will, inevitably, remain underdevelop or may getting more worst. 


\section{Acknowledgement}

With grateful thanks to all the respondents who participated in the study and those person gives strong supports to us while carrying out this crucial task (completing the study) which goes especially to our parents, spouse, daughter and son, and friends.

\section{References}

Agresti, A. \& Finlay, B. (1986). Statistical Method for the Social Sciences. San Francisco: Dellen Publishing Company.

Barbie, E. (1995). The Practice of Social Research. California: Wadsworth Publishing Co.

Duska, R. F. (2007). Whistle blowing and Employee Loyalty. Contemporary reflections on business ethics, 23, Springer.

Kinnear, R. R. \& Gray, C. D. (2000). SPSS for Windows Made Simple: Release 10. Hove: Taylor and Francis.

Santrock, J.W. (2007). A Topical Approach to Life-Span Development. New York, NY: McGraw-Hill.

Shamsul Amri Baharuddin. (2007). Modul Hubungan Etnik. Shah Alam: Pusat Penerbit Universiti.

World Travel and Tourism Organization and International Hotel and Restaurant Association (1999). Tourism and Sustainable Development: The Global Importance of Tourism (Background Papar No. 1.) New York: Commision on Sustainable Development, Department of Economic and Social Affair.

\section{Appendix 1}

Table 1. The Sample

\begin{tabular}{|l|c|l|}
\hline Group of Respondent & $\boldsymbol{n}$ & Total \\
\hline Urban Youth & 50 & \multirow{2}{*}{100} \\
\cline { 1 - 2 } Rural Youth & 50 & \\
\hline
\end{tabular}

Table 2. Correlation between the Second NP on Eco-Tourism

\begin{tabular}{lc}
\hline The Elements of $2^{\text {nd }} \mathrm{NP}$ & \multicolumn{1}{c}{$0.24^{* * *}$} \\
\hline Loyal to the YDPA \& Country & $0.31^{* * *}$ \\
Honest to the YDPA \& Country & $0.11^{*}$ \\
Sincere to the YDPA \& Country & \\
\hline
\end{tabular}

* $P<0.05 ; \quad$ ** $P<0.01$

\section{Appendix 2}

Table 3. Stepwise Regressions on the Factors Associated with Success of Eco-Tourism Industry in Sabah, Malaysia

\begin{tabular}{lcccc}
\hline Predictors & \multicolumn{3}{c}{ Success of Eco-Tourism Industry } & \\
Variables & \multicolumn{2}{c}{$\boldsymbol{T}$} & & $P$ \\
& & & & \\
\hline Constant & 79.243 & 42.223 & 0.012 \\
Ethical and Moral Values & 0.003 & 4.432 & 0.001 & \\
Doctrinal/Ideological Values & 0.452 & -2.187 & 0.061 & \\
Social Values & 0.033 & 4.100 & 0.022 \\
Aestheticism Values & 0.323 & 3.171 & 0.041 \\
& & & & \\
${ }^{a} A R^{2}=0.976, F=4357.011, P<0.05$ & &
\end{tabular}

